\title{
POST-HARVEST STUDIES ON REDUCING LOSSES AND MAINTAINING QUALITY OF PACKAGING ROSELLE CALYXES
}

\author{
Gomaa, R. B. A. 1, and M. Rashed Nahed ${ }^{2}$ \\ 1: Food Technology Research Institute. Agricultural Research \\ Center, Giza, Egypt. 2: Vegetable and Ornamental Dept., Fac. of \\ Agric. Damietta Univ., Damietta, Egypt
}

\begin{abstract}
The post-harvest technologies of roselle must be developed to maintaining quality. There are no appropriate structures for the shelling , drying, packaging and storage for the calyxes of Hibbiscus sabdariffa $L$ and it appears that these operations are performed under unsuitable conditions leading to the deterioration of the quality of the Hibbiscus sabdariffa, $L$ calyxes .For this, the effect of shelling methods ( hand and tools), drying processing (sun and oven drying), packaging materials and storage period on some quality of two cultivars of roselle calyxes extracts was studied. Dark and light roselle calyxes removed the seed's capsules for obtained fresh roselle calyxes one shelling hand and the other tool shelling, and the after that drying is carried out after shelling by two ways first is sun drying and second way is an oven air dryer at $55 \mathrm{C}^{\circ}$ for 36 hours to obtain $11 \%$ moisture content of dried roselle calyxes. All previously treatment of dark and light red roselle calyxes were divided into two groups randomly assigned to each of the treatment combinations one were packed in polypropylene (pp) package and the other packed in glass bottles as three hundred gram of each sample and stored for eight months at room temperature. Cultivars of roselle calyxes extracts, the packaging materials and storage period were highly significant effect for TSS, total acidity and $\mathrm{pH}$ but there are no significant different in anthocyanin with drying processing The two, three and four-way interactions were highly significant for TSS, total acidity and anthocyanin. Total soluble solids content was found to be increased by increasing storage period for both dark and light red roselle cultivars dried by (sun and oven) and packed in (polypropylene and glass bottles). Higher total soluble solids content was recorded for dark cultivar dried by oven packed in glass bottles after 8 months of storage. $\mathrm{PH}$ value for dark and light red roselle calyxes decreased with the increase in storage period for the two cultivar with two packaging material and two drying methods from zero days to the end of storage (after 8 months). The $\mathrm{pH}$ values of dark roselle extracts was higher than that of light red roselle extracts with all treatments. Dark and light red Roselle calyxes packaged in polypropylene showed $\mathrm{pH}$ values largest compared with packaged in glass bottles. The $\mathrm{pH}$
\end{abstract}


values of dark and light red roselle calyxes extracts dried by sun was less than that dried by oven for two packaging materials after 8 months of storage. Anthocyanin value decreased in roselle calyxes extracts of both dark and light cultivars with increasing storage period with all treatments. Anthocyanin value for dark cultivar was higher than the light cultivar. Dark and light roselle calyxes extracts packaged in polypropylene had anthocyanin value higher than that packaged in glass bottles during storage periods. Total acidity of dark and light roselle calyxes extracts increased with increasing storage period for all treatments. The dark roselle calyxes recorded the higher titratable acidity than light red roselle calyxes for all treatments during storage period. Titratable acidity of dark and light red roselle was highly with roselle calyxes dried by oven for two packaging materials throughout storage. Roselle calyxes packed in (pp) gave the lowest value titratable acidity as compared with roselle calyxes extracts packed in glass bottles for two cultivars.

Keywords: Post-harvest, reducing losses, maintaining quality, packaging, and Roselle calyxes

\section{INTRODUCTION}

Roselle (Hibiscus sabdariffa L.) is a tropical annual shrub belongs to family Malvaceae, is mainly grown in tropical and subtropical regions of Africa and Asia. It is an annual herbaceous shrub cultivated for its leaves, stem, seed and calyxes (Umerchuruba, 1997). The fresh or dried calyxes of roselle are used to prepare beverages especially as tea, jelly and syrup. The swollen calyxes are the plant part of commercial roselle interest. As the flowers fall off, the bright red calyxes swell. These are harvested, dried, and sold whole to the herbal tea and beverage industry. The flavor is a combination of sweet and tart (Plotto, 2007). In Egypt the dried calyxes are prepared into a nutritious refreshing drink called in 'karkade' and are made from an extract or infusion obtained by aqueous extraction. The indigenous beverage 'karkade' is commonly believed by Egyptians to have been consumed in ancient Egypt as a preferred drink of haraohs. Nowadays, the drink is becoming popular because it easily prepared at home and affordable. It is highly associated with Ramadan 'fasting month' and is one of the favorite drinks for the after breakfast and suhoor meal before sunrise (Ramirez, et al. 2010).

Most of the hibiscus plant's economic value comes from the red calyx as an ingredient in herbal teas, although the items are used in making rope in Africa and the seeds are expressed for the oil (Ramirez 2010).The flowers of Hibiscus sabdariffa L. contain anthocyanin , flavonoid and polyphenol (Lin, et al., 2007). Dark red cultivar of roselle were higher in $\mathrm{pH}$ and Anthocyanin value while nearly to light red cultivar in total soluble solids content . High total 
soluble solids content was recorded for dark red cultivar packed in low density polyethylene (LDPE) and extracted with acidic water (2\% citric acid) at $100{ }^{\circ} \mathrm{C}$ for $90 \mathrm{~min}$ [Gomaa and Rashed, 2011]. Anthocyanin is relatively unstable and because of their high reactivity it may be easily degraded and form colorless or undesirable brown - colored compounds during extraction processing and storage (Durst and wrolstad, 2001) Indeed, temperature, $\mathrm{pH}$, light oxygen, metals, organic acids, sugars, ascorbic acid, enzymes, sulfer dioxide, co pigmentation and interactions with food components may affect both the structure and stability of anthocyanins [Zuhaili , et al., 2012].

The most commonly consumed varieties of roselle in Egypt are made from the local variety. The calyxes are sun dried, stored and used year round. The extraction is typically carried out between $25^{\circ} \mathrm{C}$ (ambient temperature) for up to $12 \mathrm{~h}$ and $100^{\circ} \mathrm{C}$ (boiling temperature) for minutes from which the pigment or flavor embedded is extracted [Ibrahim, et al., 2004. Bhat et al. 2007].

Drying process plays an important role in the preservation of agricultural products [Waewsak et al., 2006]. It enhances the resistance of high humid products against degradation by decreasing their water activity [Hadrich et al., 2008; Simal et al., 2005) as the losses of fruits and vegetables in developing countries are estimated to be $30-40 \%$ of the production [Azharul Karim and Hawlader, 2006)]. Therefore, in many agricultural countries, large quantities of food products are dried to improve shelf life, reduce packaging costs, lower weights, enhance appearance, retain original flavor and maintain nutritional value [Baysal et al., 2003; Demir et al., 2007; Simal et al., 2000]. The traditional open sun drying method utilized widely by rural farmers has inherent limitations; high crop losses ensue from inadequate drying which results to fungal attacks, insects, birds and rodent's encroachment, unexpected down pour of rain and other weathering effects [Ekechukwu and Nortonb, 1999]. In such conditions, solar-energy crop dryers increasingly appear to be attractive as viable alternative to open sun drying, where a quicker and controlled dying process can be achieved, and the crops are well protected during the process. Dehydration is dependent on two fundamental processes; the transfer of heat into the product and subsequent removable of moisture from it, which are, heat and mass transfer processes, respectively [Potter and Hotchkiss, 1995].

Packaging materials often used includes: plastic bottles, glass bottles and polyethylene sachets. In most cases there are no considerations for the suitability of these packaging materials [Nwafor and Ikenebomeh, 2009]. The dried calyxes are harvested and sold in bulk or in individual packages. For export, dried calyxes are baled in batches of $50 \mathrm{~kg}$ in woven polypropylene bags. Packaging dried calyx 
in polypropylene bags is the most widely used because of the good ventilation allowed by this type of packaging and the low cost. The price per bag varies between 50 and 100 FCFA ( 0.08 and 0.15 euro). This conditioning is used both by producers and collectors. [Jacobs and Hounhouigan, 2010].

Operations of shelling and drying roselle are carried out manually. These operations lead to a raw material of heterogeneous quality. During the production of roselle calyces,, $L$, the main problem is the lack of adequate technical resources. The women rely on their knowhow and experience to determine the end of each step. This could result in a heterogeneous production process and in medium or poor quality beverages. After harvesting, dried calyx of roselle calyces, undergoes the steps of shelling, drying, packaging and storage. Decortication scouring is a delicate manual operation, and requires a skilled workforce. It involves taking the fruit between two hands and then making a vertical incision with both thumbs to separate the capsule and calyx. It is often difficult and painful because of the pressure required to separate the calyx and capsule and for some varieties, the presence of irritating stinging hairs. In addition, the red color of calyx turns brown or black after 3 months of storage. In fact, there are no appropriate structures for the shelling, drying, packaging and storage for the calyx of roselle calyces,. Therefore, this study sought to determine the optimum postharvest conditions which may be maintenance the fruit shape and quality of both dark and light red roselle calyces, starting from the harvest to the handling by: (1) washing (2) Method of separating calyxes from fresh roselle fruits (3) drying method (4) packaging materials during storage at room temperature for eight months.

\section{MATERIALS AND METHODS}

This investigation was carried out during the two successive seasons of 2014 and 2015, at the lab of the Food Technology Dept., Agriculture Research Center, Sakha station, Karl El-Sheikh Governorate, Egypt.

\section{Source of Roselle calyxes (Hibiscus sabdariffa L.):}

Seeds of the two cultivars of Roselle calyxes (Hibiscus subdariffa L.). dark and light red roselle were obtained from Medicinal and Aromatic Dept., A. R. C and sown at the Experimental Farm of Sakha Horticulture Research Station , Kafr El-Sheikh Governorate, Egypt, on $10^{\text {th }}$ and $18^{\text {th }}$ May in the first and second seasons, respectively. The seeds were planted in hills at $30 \mathrm{~cm}$ distance on rows $60 \mathrm{~cm}$ apart in plot and were harvested on $9^{\text {th }}$ and $14^{\text {th }}$ November in the both seasons, respectively for the two cultivars. 


\section{Preparation of roselle calyxes}

At the field we cut the base of the flower stalk with a knife to release the capsule. After harvesting fresh dark and light red roselle fruit were divided into two groups to remove the seed's capsules for obtained fresh roselle calyxes one shelling hand and the other tool shelling Figures 1 and 2.

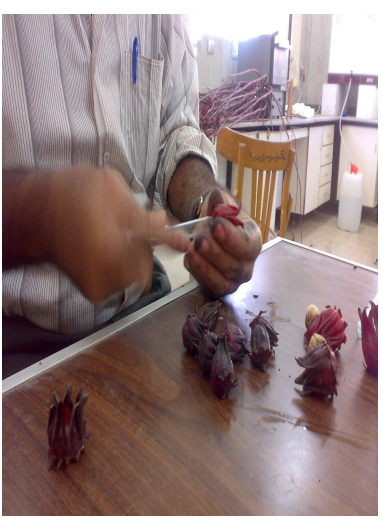

Calyx roselle

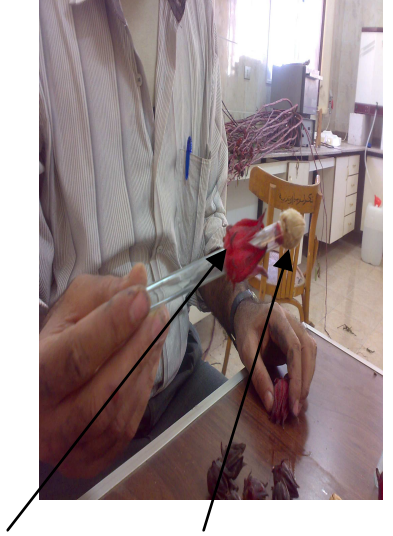

capsule

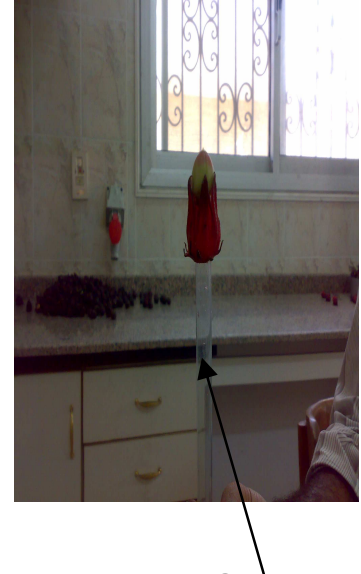

Gadget

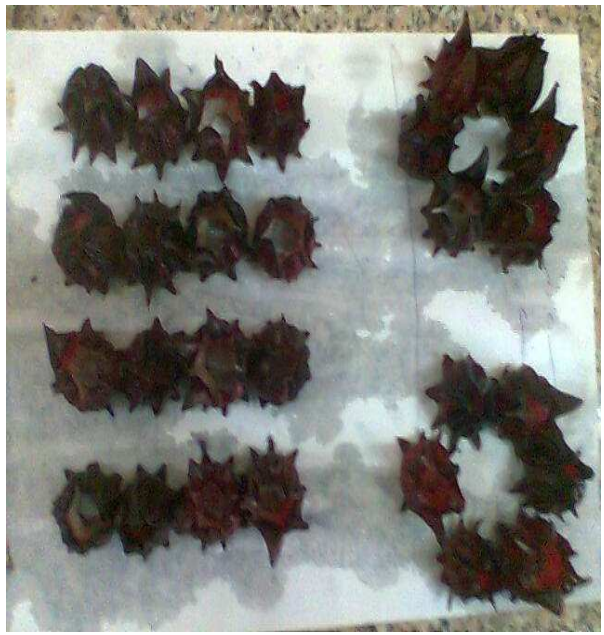

a. dark red rosell

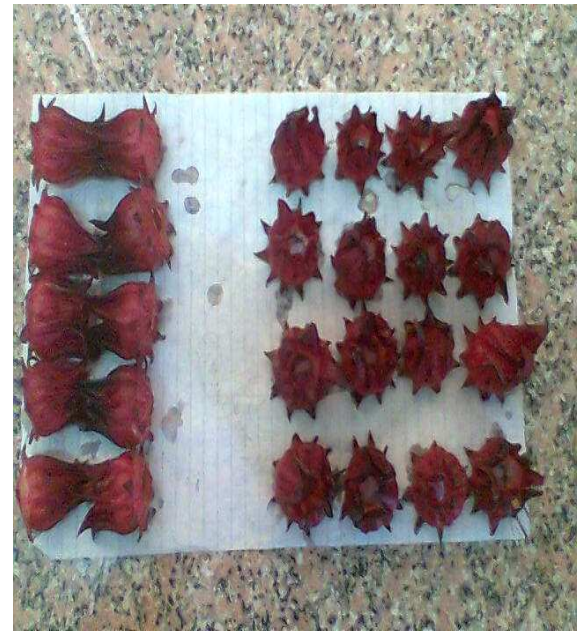

b . light red roselle

Figure 1. Tool shelling 
The two cultivars for the two processing were washed and the after that drying is carried out after shelling. By two ways first is sun drying. It reduces the moisture content of the calyx from $86 \%$ to $14-16 \%$ for improved preservation. Currently drying is traditionally performed by direct exposure of the calyx to the sun. Calyxes are spread on mats or plastic sheets placed directly on the ground. The duration of drying is between 6 and 10 days. Second way is an oven air dryer at $55 \mathrm{C}^{\circ}$ for 36 hours to obtain $11 \%$ moisture content of dried roselle calyxes. All previously treatment of dark and light red roselle calyxes were divided into two groups randomly assigned to each of the treatment combinations one were packed in polypropylene (pp) package and the other packed in glass bottles as three hundred grams of each sample.
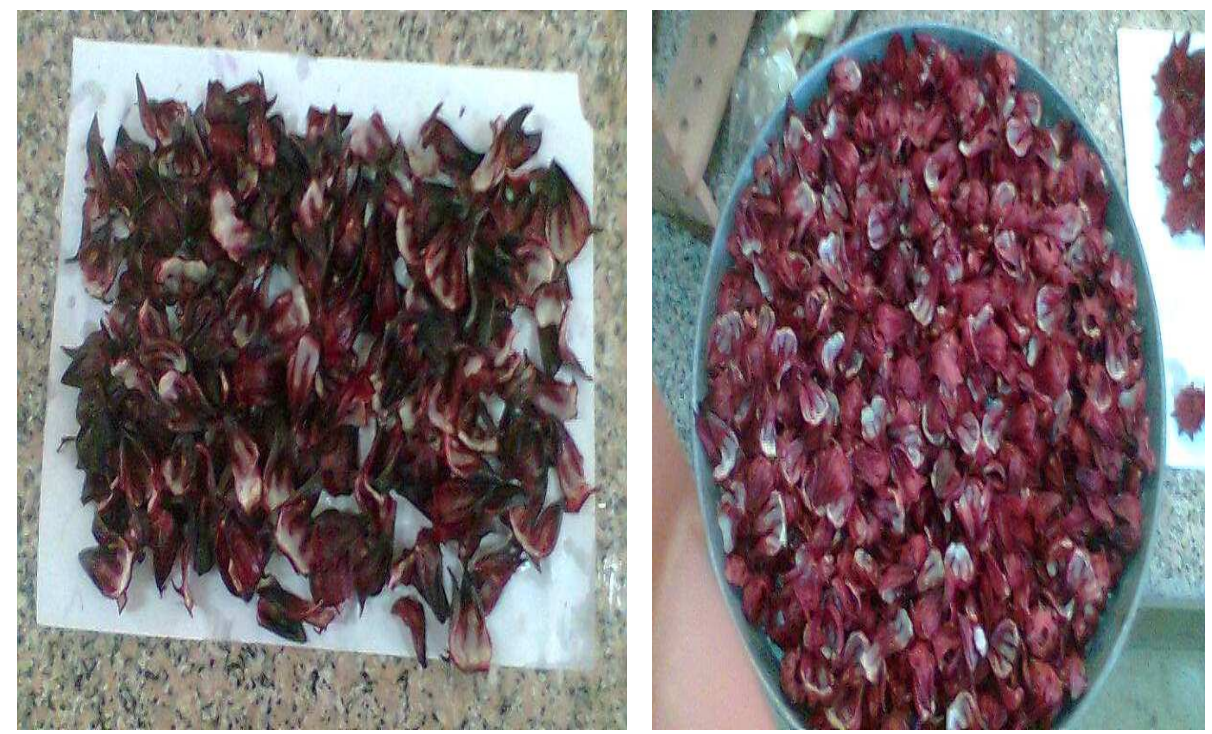

Figur 2. Hand shelling

\section{Storing treatments}

All samples were stored at room temperature (at $25^{\circ} \mathrm{C}$ ). Various quality indices along with subjective evaluation were determined during storage period up to eight months at room temperature. The physical and chemical properties of two cultivars of roselle calyxes were determining on zero day and after every two months.

\section{Treatments:-}

3.1 methods of separating 1 - Traditional processing (hand shelling) 


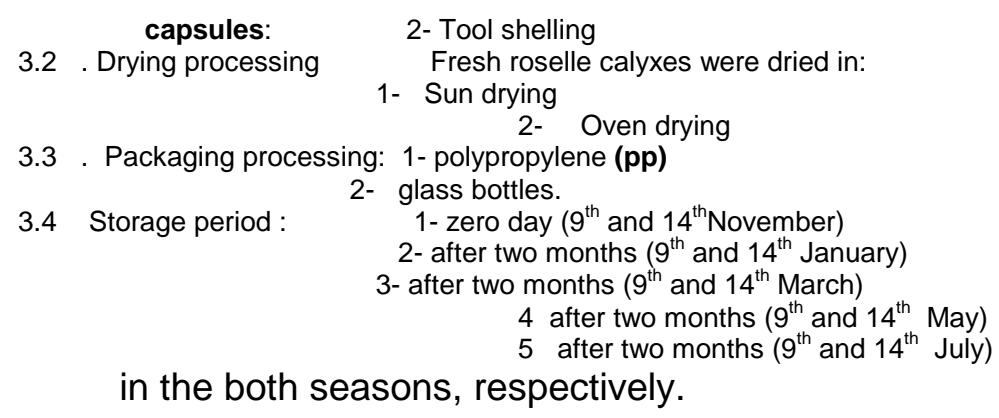

\section{4) Source of packaging materials}

- Polypropylene (pp thickness 55u) was obtained from the Islamic Company for packages in $6^{\text {th }}$ October city, Giza, Egypt. The sealed package size was $20 \mathrm{~cm} \times 30 \mathrm{~cm}$. Glass bottles are available in the Egyptian local market, Kafr El-Sheikh Governorate.

5) Source of chemicals: All chemicals' materials used were food grade and were bought from local market

\section{Physical and chemical properties:}

\subsection{Determination of \%yields of fresh and dried roselle calyxes}

The \%yield of fresh roselle calyxes was calculated as $X=$ (weight of fresh roselle calyxes after removing the seeds/weight of fresh roselle fruits) $\times 100$. The \%yield of dried roselle calyxes was calculated as $\mathrm{Y}=$ (weight of fresh roselle calyxes before drying/weight of dried roselle calyxes after drying) $\times 100$.

6.2. Moisture Content The amount of moisture content (MC) in a product is designated on the basis of the weight of water (i.e. dry or wet basis). On dry basis (\%) it can be calculated as follows [Ceylan et al., 2007]

6.3. Determination of total anthocyanins $(\mathbf{m g} / \mathbf{1 0 0 g})$ : Total anthocyanins content of two cultivars of roselle calyxes extract was determined calorimetrically according to the procedure described by [Du and Francis, 1973] for all treatments after all storage periods.

6.4. Determination of $\mathrm{pH}$ values: The $\mathrm{pH}$ values of dark and light red Roselle calyxes extract of the two seasons (2014-2015) were measured by the use bench top $\mathrm{pH}$ - meter for all treatments after all storage periods.

6.5. Total soluble solids content (T.S.S.): The total soluble solids content of the two cultivars of roselle calyxes was determined using hand refractometer according to method out lined in A.O.A.C.[2005] for all treatments after all storage periods. 
6.6. Titratable acidity: Total titratable acidity was determined by titrating $100 \mathrm{ml}$ of the samples with $0.1 \mathrm{M} \mathrm{NaoH}$ until pH 8.1 and the results were expressed as percent citrc acid A.O.A.C. [2000].

7. Statistical analysis: statistical analysis was conducted using the SPSS statistical Software package (v.11.5). Comparisons among the main treatment means were made using Tukeys H.S.D at (0.05)

\section{RESULTS AND DISCUSSION}

1. Effect of shelling method on some physical and chemical properties of roselle calyxes:

It has been studying the use of Chapter automated way to a shortage of manual labor, save time and maintaining quality of roselle calyxes.

1.1. The fresh and dried yield of roselle calyxes after shelling :

Data in Fig (3) showed that the percentage of fresh and dried yield\% for the two varieties of dark and light red roselle calyxes after two shelling methods (hand and tool). The highest fresh calyx yields were obtained from manual shelling for the two varieties as comparing with tool shelling. These results were due to some operators cut the base of the flower stalk with a knife to release the capsule and get a circular closed calyx. This method can damage the capsule which then opens slightly and releases the seeds. Significant losses are incurred by breaking the sepals with a knife. To reduce these losses some farmers dissect the flowers only 24 hours after harvest (Jacobs and Hounhouigan 2010). Meanwhile, the highest dry calyx yields were obtained from tool shelling for the two varieties as comparing with hand shelling. However, the difference in moisture content between them. These results are agreement with results (Paramee et al., 2008).

\subsection{Physical and chemical properties of fresh dark and light red roselle calyxes:}

Data in Table (1) refers to automated chaptering by tool were the highest content of total soluble solids, $\mathrm{pH}$, anthocyanins and moisture for fresh dark and light red Roselle calyces. While, traditional chaptering by hand recorded the lowest content for total soluble solids, $\mathrm{pH}$, anthocyanins and moisture. On the other hand, traditional shelling recorded the highest content of titratable acidity for dark and light red roselle. Therefore, it can be concluded that, the highest content from total soluble solids, $\mathrm{pH}$, anthocyanins, titratable acidity and moisture were dark red roselle calyces as comparing light red calyces. These results may be due to the difference between the used varieties. The 
high acidity in the roselle calyxes extracts is given by organic acids such as citric, malic, tartaric, hibiscus, succinic, oxalic and ascorbic acid [Suliman et al., 2011].
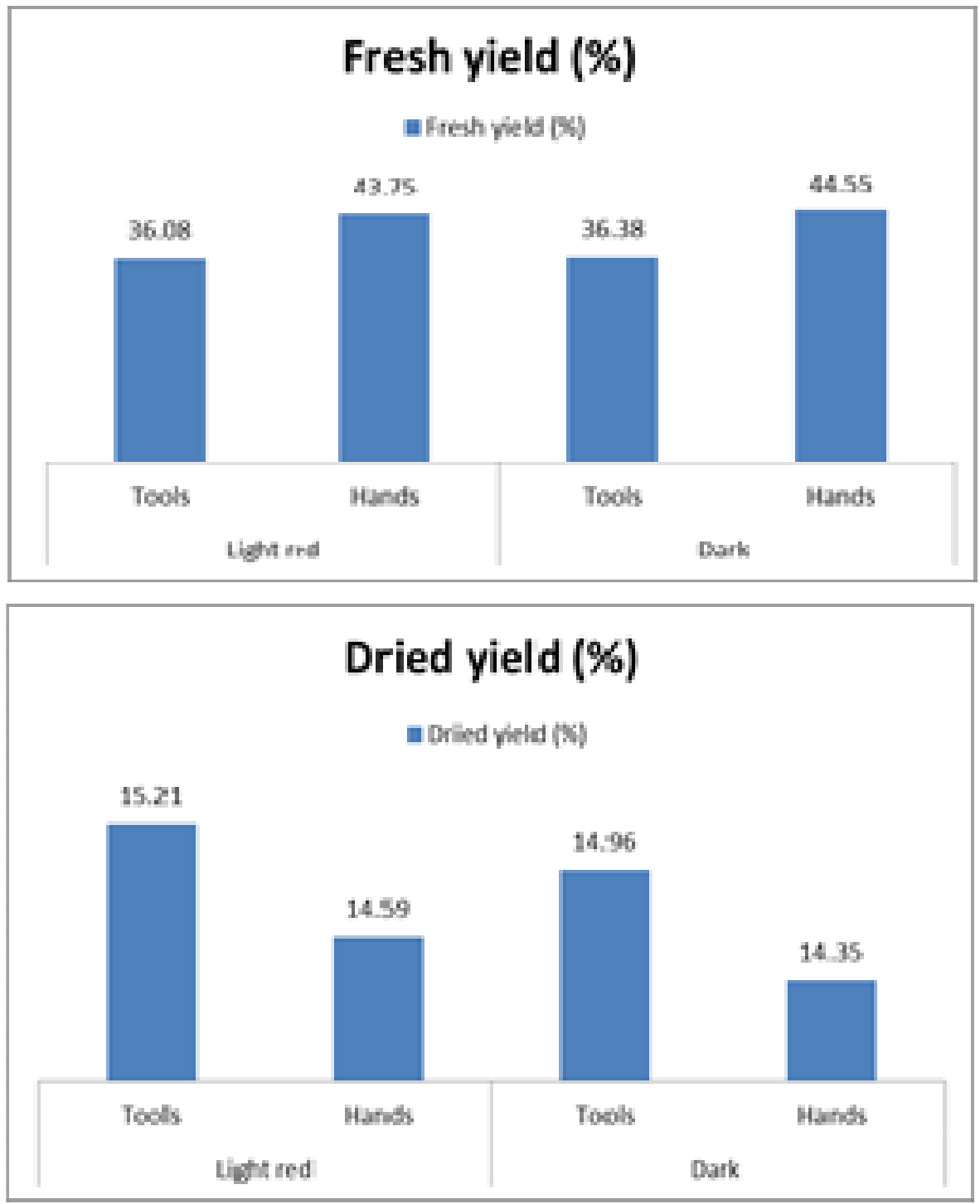

Fig (3): Fresh and dried yield \% of the dark and light red roselle calyxes 
Table (1): Physical and chemical properties of fresh Roselle calyces

\begin{tabular}{|c|c|c|c|c|c|c|}
\hline Varieties & $\begin{array}{c}\text { Methods of } \\
\text { separating }\end{array}$ & $\begin{array}{c}\text { Total } \\
\text { soluble } \\
\text { solids }\end{array}$ & $\mathrm{pH}$ & $\begin{array}{c}\text { Titratable } \\
\text { acidity } \\
(\%)\end{array}$ & $\begin{array}{c}\text { Anthocyanins } \\
(\mathrm{mg} / 100 \mathrm{~g})\end{array}$ & $\begin{array}{c}\text { Moisture } \\
(\%)\end{array}$ \\
\hline \multirow{2}{*}{ Dark } & Hands & 2.42 & 3.59 & 3.12 & 27.41 & 86.20 \\
\cline { 2 - 7 } & Tools & 2.56 & 3.74 & 3.10 & 27.48 & 86.30 \\
\hline \multirow{2}{*}{ Light red } & Hands & 2.28 & 3.47 & 3.04 & 27.01 & 81.68 \\
\cline { 2 - 7 } & Tools & 2.40 & 3.66 & 3.00 & 27.04 & 82.50 \\
\hline
\end{tabular}

2. Effect of drying methods and packaging on physical and chemical properties of dark and light red roselle calyxes during storage period:

\subsection{Total soluble solids (T.S.S) and pH}

Amount of total soluble solids (TSS) and $\mathrm{pH}$ value are important properties for quality of roselle calyxes. The low $\mathrm{pH}$ value and high TSS are indicators for the quality. Table (2) shows that the effect of packaging materials, and drying processing on TSS and $\mathrm{pH}$ of dark and light roselle calyces during storage period. These results indicated that there was variation between the TSS of roselle calyxes of both dark and light red cultivars depending on the packaging materials, drying processing and storage period. For TSS the dark roselle calyxes recorded the higher TSS than light red roselle calyces for all treatments during storage period. Also, it is noticed that TSS of dark and light red roselle were higher with oven drying for two packaging materials. Data showed that TSS of roselle calyxes dried by sun and oven were within the range of $2.60-4.10$ and $2.90-4.60$ with light red roselle calyxes, respectively. On the other hand, data also showed that TSS of roselle calyxes ranged from 3.10 to 4.90 and 3.40 to 5.00 of the dark roselle calyxes dried by sun and oven respectively, for two packaging materials and there were an increased with increasing storage period for dark and light red roselle calyces dried by sun and oven drying. The obtained data showed the correlation between methods of drying and packaging materials with the amount of TSS. Results of the investigation showed that for dark and light red roselle calyxes stored in polypropylene had the lowest TSS compared with stored in glass bottles for two drying methods during 8 months of storage. Generally, it can be concluded that the TSS an increased gradually throughout storage, this may be due to hydrolysis of polysaccharides to monosaccharides and oligosaccharides [Bhardwaj and Pandey, 2011]. Similar trend of increased TSS with storage time was observed in pomegranate kokum mango blends stored for 150 days [Waskar and Gaikwad, 2004]. Roselle calyxes extracts stored packed in glass bottles gave the highest value of TSS as compared with roselle calyxes extracts packed in polypropylene (pp) 
for two cultivars. These results are in agreement with [Beatric et al., 2015] who found that total soluble solids, increased with roselle-mango blends stored in glass bottles compared with plastic under different storage time. Also, the highest in TSS was observed in case roselle calyxes dried by oven for two cultivars. Higher total soluble solids content was recorded for dark cultivar dried by oven packed in glass bottles after 8 months of storage.

Table (2): Effect of packaging materials and drying methods on total soluble solids (TSS) and $\mathrm{pH}$ of dark and light Roselle calyxes extracts during storage period

\begin{tabular}{|c|c|c|c|c|c|c|c|}
\hline \multirow{2}{*}{\multicolumn{2}{|c|}{ Varity }} & \multirow{2}{*}{ 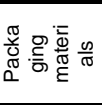 } & \multirow{2}{*}{$\begin{array}{l}\text { Storage period } \\
\text { (month) }\end{array}$} & \multicolumn{4}{|c|}{ Drying methods } \\
\hline & & & & Sun drying & $\begin{array}{l}\text { Oven } \\
\text { drying }\end{array}$ & $\begin{array}{c}\text { Sun } \\
\text { drying }\end{array}$ & $\begin{array}{l}\text { Oven } \\
\text { drying }\end{array}$ \\
\hline \multirow{8}{*}{\multicolumn{2}{|c|}{ Dark roselle }} & \multirow{4}{*}{ glass } & 2 & 3.50 & 3.80 & 3.39 & 3.49 \\
\hline & & & 4 & 3.80 & 4.10 & 3.35 & 3.46 \\
\hline & & & 6 & 4.20 & 4.50 & 3.30 & 3.40 \\
\hline & & & 8 & 4.90 & 5.00 & 3.25 & 3.34 \\
\hline & & \multirow{4}{*}{$\mathrm{pp}$} & 2 & 3.10 & 3.40 & 3.41 & 3.52 \\
\hline & & & 4 & 3.40 & 3.70 & 3.38 & 3.49 \\
\hline & & & 6 & 3.80 & 4.00 & 3.31 & 3.40 \\
\hline & & & 8 & 4.40 & 4.70 & 3.30 & 3.38 \\
\hline \multirow{8}{*}{\multicolumn{2}{|c|}{ Light red roselle }} & \multirow{4}{*}{ glass } & 2 & 3.00 & 3.30 & 3.36 & 3.42 \\
\hline & & & 4 & 3.30 & 3.60 & 3.33 & 3.39 \\
\hline & & & 6 & 3.60 & 3.90 & 3.29 & 3.35 \\
\hline & & & 8 & 4.10 & 4.60 & 3.26 & 3.30 \\
\hline & & \multirow{4}{*}{$\mathrm{pp}$} & 2 & 2.60 & 2.90 & 3.36 & 3.48 \\
\hline & & & 4 & 3.00 & 3.20 & 3.33 & 3.45 \\
\hline & & & 6 & 3.30 & 3.50 & 3.30 & 3.39 \\
\hline & & & 8 & 3.90 & 4.10 & 3.27 & 3.36 \\
\hline \multicolumn{2}{|c|}{ Treatments } & Varieties & Drying methods & \multicolumn{2}{|c|}{ Packaging materials } & \multicolumn{2}{|c|}{ Storage period } \\
\hline \multirow{2}{*}{ 옹 } & TSS & 0.0075 & 0.0075 & \multicolumn{2}{|c|}{0.0075} & \multicolumn{2}{|c|}{0.0039} \\
\hline & $\mathrm{pH}$ & 0.0033 & 0.0033 & \multicolumn{2}{|c|}{0.0033} & \multicolumn{2}{|c|}{0.002} \\
\hline
\end{tabular}

$\mathrm{PH}$ value is considered the one of main factors that limits the acceptability of given product by consumers. Also data in Table (2) showed that the mean values of $\mathrm{pH}$ for dark and light red roselle calyxes dried by sun and oven packed in glass bottles and polypropylene stored for 8 months .Data in table (2) evident that there was variation in the $\mathrm{pH}$ value of roselle calyxes extracts of both dark and light red cultivars depending on the packaging materials, methods of drying and storage period. The mean values of $\mathrm{pH}$ for dark and light red roselle calyxes decreased with the increase in storage period for all treatments. The $\mathrm{pH}$ value of dark and light red cultivars decreased for two packaging materials and both methods dry (sun and oven). The $\mathrm{pH}$ value of light red Roselle calyxes extracts was less than that of dark Roselle calyxes extracts with all treatments. Such results are confirmed by those obtained by [Beristain et al., 1994]. As dark and light red roselle calyxes packaged in polypropylene(PP) showed $\mathrm{pH}$ values largest compared with packaged in glass bottles. Also, it is 
noticed that $\mathrm{pH}$ values of dark roselle largest compared with light red Roselle. The $\mathrm{pH}$ value for dark roselle calyxes extracts stored in $\mathrm{pp}$ and glass bottles ranged from 3.30 to 3.52 and 3.25 to 3.49 respectively. While for light red roselle calyxes ranged from 3.27 to 3.48 and $3.26-3.42$ respectively during 8 months of storage. Also, it is noticed that the $\mathrm{pH}$ values of dark and light red roselle calyxes dried by sun was less than that dried by oven for two packaging materials. Data showed that $\mathrm{pH}$ values of roselle calyxes dried by sun and oven were within the range of 2.25-3.41and 3.30-3.52with dark and light red Roselle calyxes, respectively. It can be concluded that the higher decrease in $\mathrm{pH}$ values was recorded for the two cultivars with two packaging material and two drying methods from zero day to the end of storage (after 8 months). The pH value of dark and light red roselle calyxes ranging from $3.30-3.49$ and $3.27-3.42$ respectively. The low $\mathrm{pH}$ value for dark and light red roselle calyxes was due to the acidic nature of the roselle calyxes and the fruits. Roselle is characterized as a highly acidic fruit rich in organic acids: oxalic, tartaric, malice and succinic [Wong et al., 2002].

\subsection{Total Anthocyanin content and titratable acidity:}

The effect of packaging materials and drying processing on anthocyanin and titratable acidity of dark and light roselle calyxes extracts during storage period are shown in Table (3). Roselle calyxes are rich in anthocyanin, and considered to be one of the important sources of anthocyanin which render health benefits as a good source of antioxidants as well as a natural food colorant. Data in Table (3) showed that the anthocyanin value $(\mathrm{mg} / 100 \mathrm{~g})$ decreased in roselle calyxes extracts of both dark and light cultivars with increasing storage period. Also, it is noticed that anthocyanin value for dark cultivar was higher than the light cultivar. Whereas ranged from 25.03 to 26.88 and 24.48 to $26.77 \mathrm{mg} / 100 \mathrm{~g}$, respectively. Similar results were reported by [Sato et al., 1991 and Chumsri et al., 2008].

The effect of packaging materials on anthocyanin content (mg/100g) indicated that, as dark and light cultivars packaged in polypropylene (pp) was higher than that packaged in glass bottles during storage periods. It is ranged from 25.44 to $26.88 \mathrm{mg} / 100 \mathrm{~g}$ and 25.24 to $26.77 \mathrm{mg} / 100 \mathrm{~g}$ for dark and light cultivars packaged in pp, while it ranged from 25.44 to $26.88 \mathrm{mg} / 100 \mathrm{~g}$ and 25.24 to 26.77 $\mathrm{mg} / 100 \mathrm{~g}$ for packaged in glass bottles respectively. Results showed also that anthocyanin content was affected by both of drying methods (sun and oven). Where caused a decrease in anthocyanin content for dark and light cultivars at all different used packaging materials and storage period. These results may be due to caused degradation 
compounds produced in these reactions and are probably quite complex. These results are in agreement with [Patricia et al.2009] who found that anthocyanin content was decreased during drying. Also, [Cisse et al. 2011] found that factors like light, $\mathrm{pH}$, temperature, oxygen, ascorbic acid, and sugar are contributing factors in degradation or stability of anthocyanins.

Table (3) Effect of packaging materials and drying methods on Anthocyanin $(\mathrm{mg} / 100 \mathrm{~g})$ and Titratable acidity (\%) of dark and light Roselle calyxes extracts during Storage period

\begin{tabular}{|c|c|c|c|c|c|c|c|}
\hline \multirow{2}{*}{\multicolumn{2}{|c|}{ Varity }} & \multirow{2}{*}{ 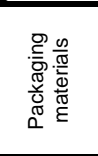 } & \multirow[t]{2}{*}{$\begin{array}{l}\text { Storage period } \\
\quad \text { (month) }\end{array}$} & \multicolumn{2}{|c|}{$\begin{array}{l}\text { Anthocyanin } \\
(\mathrm{mg} / 100 \mathrm{~g})\end{array}$} & \multicolumn{2}{|c|}{$\begin{array}{c}\text { Titratable } \\
\text { acidity } \\
(\%)\end{array}$} \\
\hline & & & & $\begin{array}{c}\text { Sun } \\
\text { drying }\end{array}$ & $\begin{array}{l}\text { Oven } \\
\text { drying }\end{array}$ & $\begin{array}{c}\text { Sun } \\
\text { drying }\end{array}$ & $\begin{array}{c}\text { Oven } \\
\text { drying }\end{array}$ \\
\hline \multirow{8}{*}{\multicolumn{2}{|c|}{ Dark roselle }} & \multirow{4}{*}{ glass } & 2 & 26.73 & 26.81 & 2.90 & 3.11 \\
\hline & & & 4 & 25.93 & 25.82 & 3.12 & 3.31 \\
\hline & & & 6 & 25.43 & 25.50 & 3.63 & 3.75 \\
\hline & & & 8 & 25.03 & 25.15 & 4.00 & 4.09 \\
\hline & & \multirow{4}{*}{$\mathrm{pp}$} & 2 & 26.82 & 26.88 & 2.88 & 3.09 \\
\hline & & & 4 & 25.87 & 26.08 & 2.97 & 3.17 \\
\hline & & & 6 & 25.62 & 25.78 & 3.51 & 3.63 \\
\hline & & & 8 & 25.44 & 25.61 & 3.92 & 4.00 \\
\hline \multirow{8}{*}{\multicolumn{2}{|c|}{ Light red roselle }} & \multirow{4}{*}{ glass } & 2 & 26.56 & 26.68 & 2.87 & 3.05 \\
\hline & & & 4 & 24.78 & 24.89 & 3.06 & 3.25 \\
\hline & & & 6 & 24.52 & 24.48 & 3.62 & 3.71 \\
\hline & & & 8 & 24.48 & 24.41 & 3.95 & 4.03 \\
\hline & & \multirow{4}{*}{$\mathrm{pp}$} & 2 & 26.71 & 26.77 & 2.79 & 2.99 \\
\hline & & & 4 & 25.89 & 25.89 & 2.96 & 3.15 \\
\hline & & & 6 & 25.54 & 25.56 & 3.49 & 3.61 \\
\hline & & & 8 & 25.24 & 25.57 & 3.91 & 4.00 \\
\hline & Treatments & Varieties & Drying methods & Packag & aterials & Stor & eriod \\
\hline \multirow{2}{*}{ 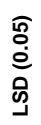 } & Anthocyanin & 0.169 & 0.169 & \multicolumn{2}{|c|}{0.169} & \multicolumn{2}{|c|}{0101} \\
\hline & Total acidity & 0.0038 & 0.0038 & \multicolumn{2}{|c|}{0.0038} & \multicolumn{2}{|c|}{0.0023} \\
\hline
\end{tabular}

For, titratable acidity, initial titratable acidity was within the range of $2.78-4.09 \%$. These results indicated that there was variation between the titratable acidity of roselle calyxes extracts of both dark and light red cultivars depending on the packaging materials, drying processing and storage period. These results showed that titratable acidity of dark and light roselle calyxes extracts increased steadily throughout storage for all treatments. The dark roselle calyxes recorded the higher titratable acidity were $(2.88-4.09)$ than light red roselle calyxes were $(2.78-4.05)$ for all treatments during storage period.

Also, it is noticed that titratable acidity of dark and light red roselle was highly with roselle calyxes dried by oven for two packaging materials throughout storage. Dark and light red roselle calyxes extracts packed in polypropylene (pp) gave the lowest value titratable acidity as compared with roselle calyxes extracts packed in glass bottles for two cultivars. Whereas ranged from 2.88 to $4.00 \%$ and 2.90 to $4.09 \%$ 
respectively, for dark cultivar and ranged from 2.79 to $4.00 \%$ and 2.87 to $4.03 \%$ respectively, for light red cultivar. The high rate of change in titratable acidity for dark and light roselle calyxes extracts during storage period could be due decomposition of fermentatable substrate especially the carbohydrates in the fruits thereby increasing the acidity. These results are in agreement with [Fasoyiro, et al., 2005]. Also, [Wong et al., 2002] who found that roselle contains high acid, and the titratable acidity value was $2.49 \%$.

\subsection{Analyses of variance}

Summarizes the results of the analyses of variance and mean values of anthocyanin, total soluble solid (T.S.S), total acidity and $\mathrm{pH}$ of two roselle cultivars as affected by drying methods, packaging materials and storage period are shown in Table (4). Concerning the influence of cultivars, data are consistent with the fact that dark red roselle calyxes are rich in anthocyanin content, (T.S.S), total acidity and $\mathrm{pH}$ than light red roselle calyxes which recorded the higher significant means value it is well known that roselle extract is characterized by its sour taste. This is confirmed by the total acidity of roselle calyces which was as high as $3.45 \%$. In the same ways, $\mathrm{pH}$ value was a low as 3.40 . The difference between sun drying and oven drying were highly significant for TSS, total acidity and $\mathrm{pH}$ but not significant for anthocyanin. This results may be due to traditional open sun drying method has major disadvantages, such as the important risk of microbiological contamination (fungal attacks), presence of sand and debris, insects, birds and rodents encroachment, unexpected down pour of rain and other weathering effects, anthocyanins degradation and losses of nutritional compounds. The duration of drying is between 6 and 10 days. Solar-energy crop dryers increasingly appear to be attractive as viable alternative to open sun drying, where a quicker and controlled drying process can be achieved, and the crops are well protected during the process. Dehydration is dependent on two fundamental processes; the transfer of heat into the product and subsequent removable of moisture from it, which are, heat and mass transfer processes, respectively (Potter and Hotchkiss, 1995)

For the packaging materials effect, data in table (4) included that the packaging type had the highest significant effects for TSS, anthocyanin, and titratable acidity, but there are significant for $\mathrm{pH}$. Polypropylene recorded the highest value for anthocyanin, TSS and $\mathrm{pH}$. While, roselle calyxes packaged in glass bottles recorded highest value as $3.47 \%$ for titratable acidity. 
Table (4): Mean values of anthocyanin content, total soluble solid, $\mathrm{pH}$ and titratable acidity of two Roselle cultivars extract as affected by drying methods, packaging materials, and storage period

\begin{tabular}{|c|c|c|c|c|}
\hline Treatment & $\begin{array}{c}\text { Anthocyanin } \\
(\mathrm{mg} / 100 \mathrm{~g})\end{array}$ & $\begin{array}{c}\text { Total soluble } \\
\text { solid }\end{array}$ & $\begin{array}{c}\text { Titratable } \\
\text { acidity, } \\
(\%)\end{array}$ & $\mathrm{pH}$ \\
\hline $\begin{array}{l}\text { Cultivars, (v) } \\
\text { dark Roselle } \\
\text { light red Roselle } \\
\text { Sig } \\
\text { L S D }(0.05)\end{array}$ & $\begin{array}{c}25.960 \\
25.378 \\
\star * \\
0.169 \\
\end{array}$ & $\begin{array}{c}4.022 \\
3.497 \\
\star \star \\
0.0075\end{array}$ & $\begin{array}{c}3.446 \\
3.410 \\
* * \\
0.0038\end{array}$ & $\begin{array}{l}3.400 \\
3.356 \\
* \star \\
0.0033\end{array}$ \\
\hline $\begin{array}{l}\text { Drying, (d) } \\
\text { Sun drying } \\
\text { Oven drying } \\
\text { Sig } \\
\text { LS D }(0.05)\end{array}$ & $\begin{array}{c}25.645 \\
25.692 \\
\text { ns } \\
0.169 \\
\end{array}$ & $\begin{array}{c}3.622 \\
3.897 \\
\star * \\
0.0075\end{array}$ & $\begin{array}{c}3.353 \\
3.502 \\
\star * * \\
0.0038\end{array}$ & $\begin{array}{c}3.338 \\
3.417 \\
\star \star \\
0.0033\end{array}$ \\
\hline $\begin{array}{l}\text { packging materials, }(\mathbf{p}) \\
\text { Polypropylene } \\
\text { Glass bottles } \\
\text { Sig } \\
\text { L S D }(0.05)\end{array}$ & $\begin{array}{c}25.975 \\
25.362 \\
\star * \\
0.169\end{array}$ & $\begin{array}{c}3.953 \\
3.565 \\
* * \\
0.0075\end{array}$ & $\begin{array}{l}3.383 \\
3.472 \\
* \star \\
0.0038\end{array}$ & $\begin{array}{c}3.387 \\
3.369 \\
* \\
0.0033\end{array}$ \\
\hline $\begin{array}{l}\text { storage time(month), (s) } \\
2 \\
4 \\
6 \\
8 \\
\text { Sig } \\
\text { L S D }(0.05)\end{array}$ & $\begin{array}{l}26.505 \\
25.643 \\
25.332 \\
25.194 \\
\star \star \star \\
0101\end{array}$ & $\begin{array}{l}3.203 \\
3.516 \\
3.853 \\
4.466 \\
\star \star \\
0.0039\end{array}$ & $\begin{array}{l}2.966 \\
3.128 \\
3.626 \\
3.990 \\
* * \\
0.0023\end{array}$ & $\begin{array}{l}3.432 \\
3.402 \\
3.347 \\
3.330 \\
\star \star \star \\
0.002\end{array}$ \\
\hline $\begin{array}{l}\text { Interaction between treatments } \\
s^{*} v \\
s^{*} p \\
s^{*} d \\
v^{*} p \\
v^{\star} d \\
p^{\star} d \\
s^{*} v^{*} p \\
s^{*} p^{*} d \\
v^{*} p^{\star} d \\
s^{*} v^{*} d \\
s^{*} v^{*} p^{*} d\end{array}$ & 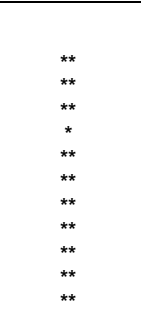 & $\begin{array}{l}\star \star \\
\star \star \\
\star \star \\
\star \star \\
\star \star \\
\star \star \\
\star \star \\
\star \star \\
\star \star \\
\star \star \\
\star \star \\
\star \star \\
\star \star\end{array}$ & 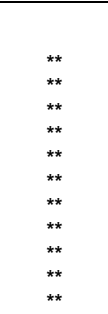 & $\begin{array}{c}\text { * } \\
\text { * } \\
\mathrm{ns} \\
* * \\
* \\
\mathrm{~ns} \\
{ }^{* *} \\
\mathrm{~ns} \\
* \\
\mathrm{~ns} \\
*\end{array}$ \\
\hline
\end{tabular}

Storage period had the highest significant effects for TSS, anthocyanin, $\mathrm{pH}$ and titratable acidity. Increasing the storage periods led to decreasing in anthocyanin and $\mathrm{pH}$. Meanwhile, increasing the storage periods led to increasing total soluble solid and titratable acidity. Also, it is noticed that of dark and light red cultivars for anthocyanin, total soluble solid, titratable acidity and $\mathrm{pH}$, the main factors; e.g. drying methods, packaging materials and storage period and were highly significant. The two - way interactions of $\left(s^{*} v\right),\left(s^{*} p\right)$, $\left(s^{*} d\right),\left(v^{*} p\right),\left(v^{*} d\right)$ and $\left(p^{*} d\right)$ were highly significant for TSS, total acidity and anthocyanin. Which indicated that the effect of packaging depends on drying methods, cultivars and also on the period of storage. Meanwhile the data showed that the two - way interactions of $\left(s^{*} d\right)$, $\left(p^{*} d\right)$ and the three- way interactions of $\left(s^{*} p^{*} d\right)$ and $\left(s^{*} v^{*} d\right)$ were not significant for $\mathrm{pH}$ which indicated that the effects of drying methods, roselle cultivars, packaging materials and storage period were independent. In addition, the three- way interactions of $\left(s^{*} v^{*} p\right),\left(s^{*} p^{*} d\right)$ and $\left(v^{*} p^{*} d\right)$ and $\left(s^{*} v^{*} d\right)$ and four way interactions of $\left(s^{*} v^{*} p^{*} d\right)$ were highly significant for TSS, total acidity and anthocyanin. 


\section{Conclusion}

This work demonstrates:

1- The importance of use chapter automated way (tool shelling) to a shortage of manual labor, save time and maintaining quality of roselle calyxes.

2- Oven dryers appear to be alternative to open sun drying, where the difference between sun drying and oven drying were highly significant for TSS, total acidity and $\mathrm{pH}$, quicker, controlled drying process can be achieved, and the yields are well protected during the process.

3- Total soluble solid (TSS) content and total acidity (\%) were found to be increased by increasing storage period for both dark and light red roselle

4- Polypropylene package is used because of higher anthocyanin and total soluble solid content was recorded for dark roselle cultivar and the good permeability allowed by this type of packaging and the low cost.

5- We can storage the two cultivars of roselle for 8monthes without deterioration by oven drying and packed it in polypropylene package (pp).

\section{REFERENCE}

A.O.A.C. (2000). Official Methods of Analytical of the Association of Official Chemists International. $17^{\text {th }}$ ed. The Association of Official Chemists International. Gaithersburg.

A.O.A.C. (2005). Offical Methods of Analysis of the Association of Offical Analytical Chemsists $15^{\text {th }}$ Ed,Arlinton, Virginia USA.

Azharul Karim, M. and Hawlader, M. N. A. (2006). Performance evaluation of a $\vee$ groove solar air collector for drying applications. Applied Thermal Engineering 26: 121-130.

Baysal, T., Ic-ier, F., Ersus, S. and Yildiz, H. (2003). Effects of microwave and infrared drying on the quality of carrot and garlic. European Food Research Technology 218:68-73

Beatric,M.K., Siv,F.R., Bernard,E.C., and Trude, w. (2015). Physiochemical and antioxidant properties of roselle-mango juice blends; effects of packaging

material, storage temperature and time. Food Sci Nutr v.3(2); 2015 Mar Pages100-109

Beristain, C.I., Mendoza, R.E. Garcia, H.S and Vazquez, A. (1994).

Cocrystallization of Jamaica (Hibiscus sabdariffa L.) granules. Lebensmittel Wissenschaft and Technologie, 27: 347-349. 
Bhardwaj, R. J., and Pandey, S. (2011). Juice blends-a way of utilization of under- utilized fruits, vegetables, and spices: a review. Crit. Rev. Food Sci. Nutr. 51:563-570

Bhat, R., Sridhar, K.R., and Yokotani K.T. (2007).Effect of ionizing radiation on antinutritional features of velvet bean seeds (Mucuna pruriens). Food Chemistry, 103: 860-866.

Ceylan, I., Aktas, M. and Dog ־an, H. (2007). Mathematical modeling of drying characteristics of tropical fruits. Applied Thermal Engineering 27: 1931-1936.

Chumsri, P., Sirichote, A.and Itharat, A.. (2008). Studies on the optimum conditions for the extraction and concentration of roselle (Hibiscus sabdariffa $L$ ) extract. Songklanakarin J. Sci. Technol. 30:133-139.

Cisse, M., Vaillant, F., Kane, A., Ndiaye, O., and Dornier, M. (2011). Impact of the extraction procedure on the kinetics of anthocyanin and colour degradation of roselle extracts during storage. J. Sci. Food Agric. 92:1214-1221.

Demir, V., Gunhan, T. and Yagcioglu, A. K. (2007). Mathematical modeling of convection drying of green table olives. Biosystems Engineering 98: 47-53.

Du, C. T. and Francis, F. J. (1973). Anthocyanins of roselle (Hibiscus sabdariffa, L). J. Food Sci., 38: 810-812.A.O.A.C.(2005)

Durst, R., and R. Wrosltad, (2001). Separation and Characterization of anthocyanins by HPLC. Food Analytical Chemistry John Wiley and Sons, Inc., USA. P. F1.3.1.

Ekechukwu, O.V. and B. Nortonb, (1999). Review of solar-energy drying systems II: an overview of solar drying technology. Energy Conversion \& Management, 40: 615-655.

Fasoyiro, O.A. Ashaye, Adeola A. and Samuel, F.O. (2005).Chemical and Storability of Fruit-Flavoured (Hibiscus sabdariffa) Drinks. World Journal of Agricultural Sciences 1 (2): 165-168, 2005.

Gomaa, R. B. A.and M.. Rashed Nahed(2011) Effect of packaging materiales, Storage conditions, cultivar and extraction methods on the extraction quality of roselle calyxes. Alexandria science exchange journal, vol. 32, NO (2) 130-139.

Hadrich, B., Boudhrioua, N. and Kechaou, N. (2008). Drying of Tunisian sardine

(Sardinellaaurita) experimental study and threedimensional transfer modeling of drying kinetics.Journal of Food Engineering 84: 92-100.

Ibrahim, N.A., Ahmad, Z.S. and. Youssef, I.A.(2004). Development of food consumption monitoring system for Egypt. 6th International Conference for Food Industries Quality Control, pp: 106-125.Alexandria, Egypt.

Jacobs, A and J. D. Hounhouigan (2010) Literature review and Background information of (Hibiscus sabdariffa , L.). African Food Tradition Revisited by Research.FP7 No (245 025)

Lin, T., H. Lin, C. Chen, M. Lin, M. Chou and C. Wang, (2007).Hibiscus sabdariffa extract reduces serum cholesterol in men and women. Nutrition Research, 27: 140-145. 
Nwafor O.E and Ikenebomeh M.J (2009), "Effects of different packaging materials on microbiological, physio-chemical and organoleptic quality of zobo drink storage at room temperature" African Journal of Biotechnology Vol. 8 (12): pp. 2848-2852. Research.FP7 No(245 025).

Paramee, C., Anchalee S., and Arunporn, I (2008). Studies on the optimum conditions for the extraction and concentration of roselle (Hibiscus sabdariffa L) extractl Songklanakarin J. Sci. Technol. 30 (Suppl.1), 133-139, April 2008.

Patricia,M.,Abdullah,M.,I., and Hashimi,M.,I.,(2009): Effect of sun and oven drying on quality of Roselle (hibiscus sabdariffa linn) school of food science and nutrition universiti malasia sabah 2009.

Plotto, A. (2007). Post-Production Management for Improved Market Access for Herbs and Spices. Post-harvest compendium. Edited by Mazaud, et al. FAO.

http://www.fao.org/inpho/content/compend/text/ch28/ch28.htm $\quad\left[\begin{array}{ll}19 & \text { June }\end{array}\right.$ 2007].

Potter, N.N. and J.H. Hotchkiss, (1995). Food Science. Chapman and Hall, New York Ekechukwu, O.V. and B. Nortonb, 1999. Review of solarenergy drying systems II: an overview of solar drying technology. Energy Conversion \& Management, 40: 615-655.

Ramirez-Rodriguez, M.M., (2010). Processing hibiscus beverage using dense phase carbon dioxide. Stat of Florida, USA, University of Florida, PhD Thesis.

Ramirez, M.M., Wysocki, A.F. Ramirez, M.A. Sims C.A. and Balaban, M.O. (2010).

Sensory and Marketing Characteristics of a Hibiscus Beverage. Journal of Food

Distribution Research, 41(3): 52-62.

Sato, K., Goda, Y. Yo.xliihira, K. and Noguchi, 11. (1991). Structure and contents of main colouring constituents in the calyces of Hibiscus sabdariffa and commercial red colour. Shokuhin, Eiscigaku Zasshi 32 (4), 301-7.

Simal, S., Femenía, A., Llull, P. and Rosselló, C. (2000). Dehydration of aloe vera: simulation of drying curves and evaluation of functional properties. Journal of Food Engineering 43:109-114.

Simal, S., Femenia, A., Garau, M. C. and Roselló, C., (2005). Use of exponential Page's and diffusional models to simulate the drying kinetics of kiwi fruit. Journal of Food Engineering 66(3): 323- 328.

Suliman, A.M.M.A., Ali, O.A. Idriss- Sharaf E.A.A. and Abdualrahman M.A.Y,(2011). Acomparative study on red and white Karkade (Hisbiscus sabdariffa $L$ ) calyxes, extracts and their products. Pakistan J. of Nutrition, $10(7), 680-683$.

Umerchuruba, C.I., (1997). An annotated list of plant diseases in Nigeria. Pen and Paper Publication, Owerri, Nigeria.

Waewsak, J., Chindaruksa, S. and Punlek, C. (2006). A mathematical modeling study of hot air drying for some agricultural products. Thammasat International Journal of Science and Technology 11(1): 1420. 
Waskar, D. P., and Gaikwad. R. S. (2004). Packaging and storage studies on Pomegranate, kokum and mango based blends. Agric. Sci. Digest. 24:174-177.

Wong, P., Salmah Cheman, Y.H.M. (2002). Physico-chemical characteristics of roselle (Hibiscus sabdariffa I.). Nutr. and Food Sci., 32: 68-73..

Zuhaili I., I. I. Muhamad, S. H. M. Setapar and M. R. Sarmidi, (2012). Effect of thermal processes on roselle anthocyanins encapsulated in different polymer

matrices. J. of food processing \& preservation, 36 (2): 176 - 184.

\title{
دراسات على تقليل الفاقد بعد الحصاد والمحافظة العربي جودة سبلات الكركدية
}

\author{
رمزى بسيونى جمعة1 , ناهد مصطفى راشد 2

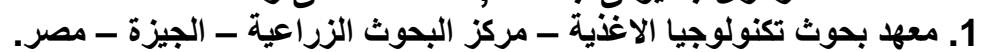

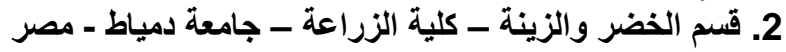

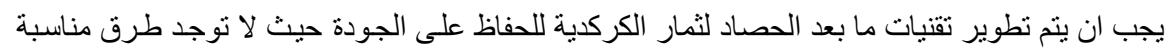

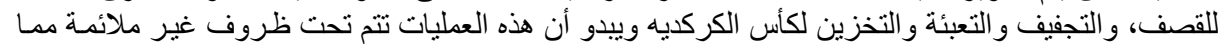

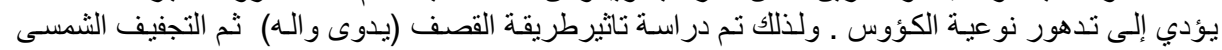

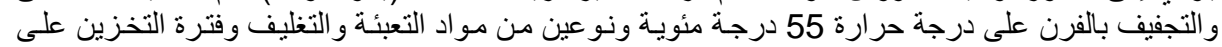

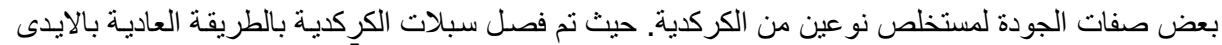

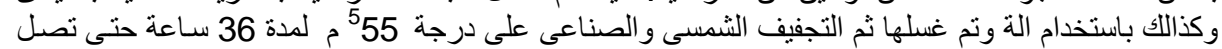

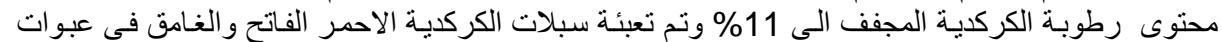

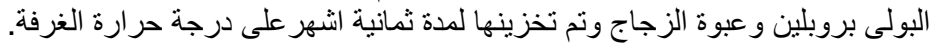

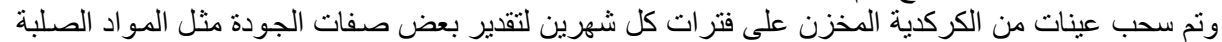

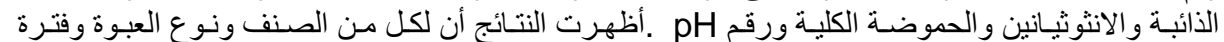

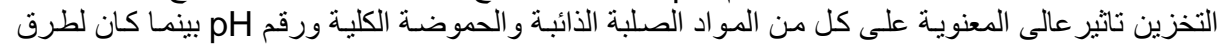

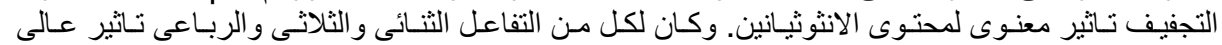

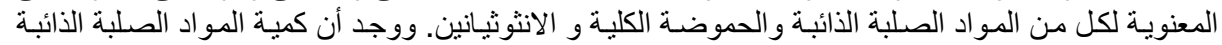

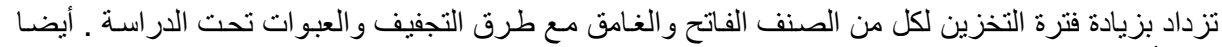

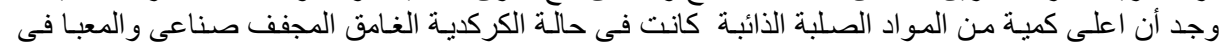

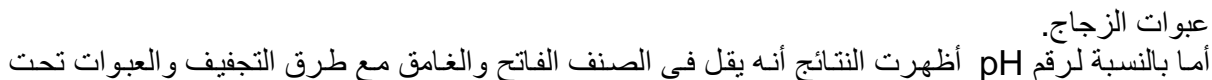

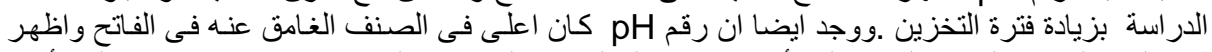

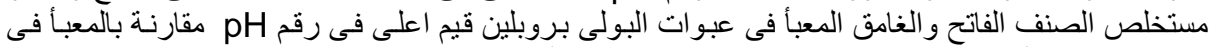

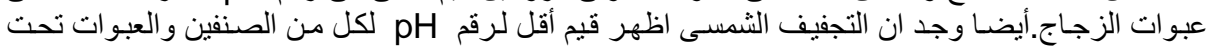

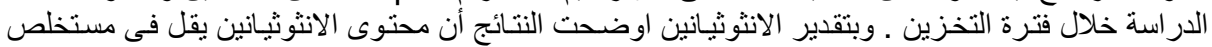

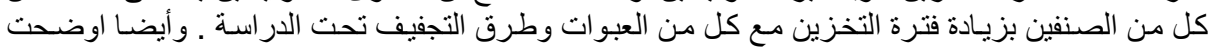

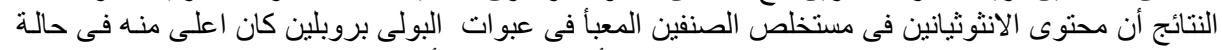

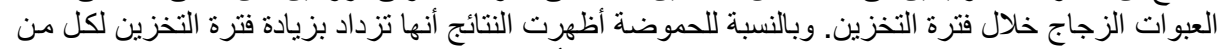

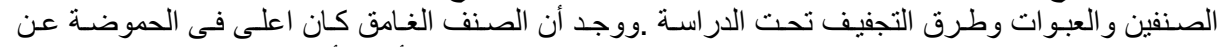

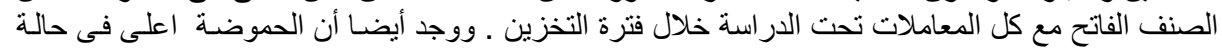

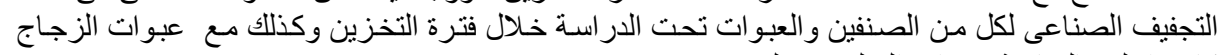
كانت اعلى بالمقارنة بعبوات البولى البى بروبلين. 